
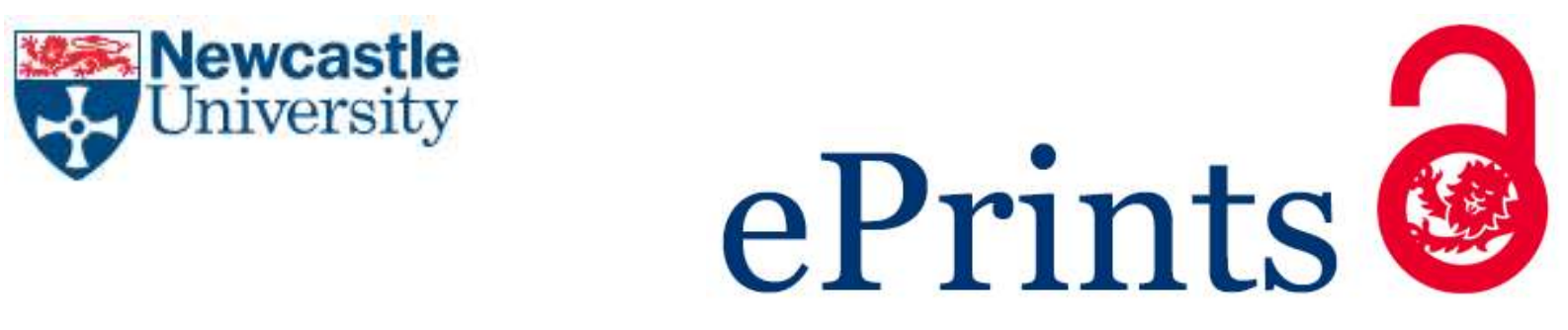

Cowie P. Performing Planning: Understanding community participation in planning through theatre. Town Planning Review 2017, 88(4), 401-421.

\title{
Copyright:
}

(C) 2017 Liverpool University Press. This is the author's version of a work accepted for publication by Liverpool University Press.

DOI link to article:

https://doi.org/10.3828/tpr.2017.26

Date deposited:

$11 / 07 / 2017$

Embargo release date:

01 July 2019

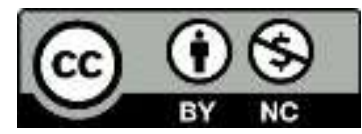

This work is licensed under a Creative Commons Attribution-NonCommercial 3.0 Unported License 


\title{
Performing Planning: Understanding community participation in planning through theatre
}

\section{Paul Cowie}

\begin{abstract}
Greater public participation in planning has long been a goal for planning professionals. In practice what often takes place is the dreaded 'community consultation' process. There is often a gulf between a community's enthusiasm and creativity and the strictures of the statutory planning process. This article reports on a performance based project which explored issues of representation and legitimacy in participatory planning. The use of theatre as a tool to investigate participatory planning has proved to be a powerful one which has sparked their enthusiasm, interest and imagination.
\end{abstract}

\section{Keywords}

Public Participation; Theatre; neighbourhood planning; legitimacy; representation.

\section{Introduction}

Picture the scene: it's a cold Tuesday night in a community hall somewhere in the north of England. Gathered in the hall are the local residents, turned out en-masse to be 'consulted' about a new major planning proposal for their community. In the wings the planning officer fidgets and prepares his papers, glances at his prepared statement, draws a deep breath, ready to go out and confront the community.

This is an experience the author has had first hand as a local authority solicitor advising the planning committee. It is also a more recent experience as an academic. This time the situation was staged as part of a theatrical performance. The local residents in this case have been the audience and the planning officer an actor.

This paper outlines the results of this a performance based project which uses theatre as a research tool to assist planners and communities to understand participate in planning. One of the problems in the planning system is its perceived inability to connect communities' concerns and visions with the hard reality of statutory planning processes (Bailey \& Pill, 2015). This interrelationship between the statutory processes and local participation has been an issue for local government for a significant period of time. This research attempts to explore these issues in a robust and innovative way which engages the community in the process of discovery rather than treating them as subject of study. 
Theatre offers the opportunity to manipulate time and create a scenario which allows communities, over the space of a few hours, to experience a planning issue which may unfold over a significant period of time. In this way communities can be guided to a deeper understanding of the planning process and start to engage in planning at a more strategic level.

Whilst over the last 40 years there have been many attempts to allow those affected by planning decisions to have a say in the process of strategic plan making (see Damer and Hague, 1971), the move to greater participation in planning has gained a further impetus as a result of the 'Localism' agenda (Gallent \& Robinson, 2012). This is complimented by a wider literature examining public participation in politics more generally. Lowndes et al (2001) highlighted the proliferation of participatory methods adopted by local government at the turn of the millennium. More recently Fung (2015) has highlighted the possibility that better public participation in governance issues may help overcome issues of effectiveness, legitimacy and social justice.

However, it is often difficult to research community participation in planning in a systematic and robust way. Communities are heterogeneous both in their composition and the planning issues they face, particularly when they are seeking to respond to societal scale issues such as an aging population and climate change. The project aims to develop a new method of public participation that allows greater deliberation on not just the problem at hand but also the way the problem is framed by both planners and the community.

The play; 'The Town Meeting'; was co-created by the author and a local theatre company. The play is set in a fictitious town faced with a significant planning decision. The audience fully participate determining the direction the play takes during the performance. To date the play has been performed in 14 venues across the northeast (though this paper only covers the first 8 venues), ranging from one of the most remote rural communities in England to the urban centres of Newcastle, Leeds and Sheffield. The results of the research have revealed some intriguing insights into process of public participation.

This project set out to create a piece of theatre which was both entertaining and stimulating in the way it engaged communities. In contrast to similar collaborative planning initiatives such as 'planning for real' or participatory budgeting, theatre is immersive and fully interactive with the audience having a significant degree of control over the direction the process takes. In addition with a live theatre performance, as Dolen explains 'suddenly and unexpectedly we are lifted from our normal detached contemplation into another place, where time stops, and our breath catches' (2005: 8). The immersive nature of theatre fosters transformative thinking about planning problems where not just the problem at hand is tackled but also the underlying assumptions that frame the planning issue.

This paper seeks to contribute to the recent literature and research around community participation in planning (see for example Sturzaker \& Shaw, 2015; Parker \& Street, 2015; Parker et al., 2015, Gallent, 2013 and Davoudi \& Cowie, 2013). The research method allows a deeper understanding the nature of representation within processes based on deliberative democracy rather than representative democracy (Saward, 2000). By necessity communities must organise themselves informally when engaging in the planning system. Their legitimacy and power when doing so is derived from their ability to claim to speak for that community. This could be through submitting evidence to planning consultation, making representations in relation to a planning application or by 
producing a neighbourhood plan for their community. The research used Hannah Pitkin's (1967) forms of representation as the framework to understand in greater detail how these self-organising groups manage this process. The first section of the paper considers the nature of representation and how this relates to community participation in planning.

The paper then goes on to consider how important the process of planning is to successful and meaningful public participation. It raises questions of agency on the part of the community and how the way the statutory structure of the planning system is applied by planning professionals can have serious consequences for community participation. Here the paper draws on Parker \& Street's (2015) concept of political modulation.

The paper then briefly outlines the methodology used in the research and gives an overview of the fieldwork. The main discussion section of the paper sets out the findings of the research and explores how the findings broaden and deepen our understanding of community participation in planning. Finally the paper sets out how the research is being taken forward and makes some suggestions for both planning research and practice in particular as a means of bringing about transformative thinking about place as suggested by Healey (2016).

\section{Participation in planning}

Over the last few decades the legitimacy of traditional democratic institutions has been questioned (Judge, 2013 \& Fung, 2015). Planning as an institution has not been immune, with communities feeling distanced and powerless in relation to the planning issues affecting them (Bailey \& Pill, 2014). Traditionally the Planner's role has been to aggregate the views of communities and then co-opt this knowledge into the techno-rational planning system (Bradley, 2015). The primary means by which the planner seeks to ascertain the views of the community is through a process of consultation. This has not always been completely satisfactory for either the planner or the community, with consultation events often viewed by those being consulted as having no meaningful impact on planning outcomes (Brownill, 2009).

Moves to increase community participation in planning have a long history dating back as far as the 1970s with the Skeffington Report on Public Participation in planning (Skeffington, 1970). Discussion of the nature of public participation in planning has also been the subject of academic endeavour for a similar period (see Hillier \& Healey, 2008) with participation in planning being seen as a way of overcoming the perceived problems of the planning system, its adversarial nature and lack of power for those most affected by the system. Academics have been discussing participation in politics for even longer, perhaps the best know paper on the subject is Sherry Arnstein's (1969) paper setting out her 'ladder of citizen participation'. In the ladder, participation was ranked from nonparticipation and tokenism through to the ideal type, citizen control. This normative basis for differentiating participation has been challenged recently by other methods of differentiating participation (Fung, 2006) and the fact that citizen control may not be appropriate in every circumstance. Both Bishop (2015) and Fung (2015) for example proposes using a suite of participatory methods which, like ingredients in a recipe, can be mixed and matched to fit the circumstances. 
Dean (2016) has taken issue with both these approaches to understanding participation. Dean (ibid) introduces a matrix typology which differentiates participation on by the degree they are inclusive and the degree of influence the community has over the final decision. Fung (2006) takes this one step further. As well as the inclusivity of the process, he also categorises participation by the authority and power possessed by the community and the decision making process. This paper focuses on strategic plan making which is intended to be collaborative, with planers and the community they are planning for negotiating the terms of the plan. Although this often takes the form of a decide - announce - defend process with community consultation taking place on a draft plan which is all but complete.

More recently there has been a call to move to a post-collaborative form of planning (Watson, 2014). Drawing on the experience of community activists in the global south Watson (ibid) calls on planners to have as a goal the use of co-production methods of planning. These would fall within the 'negotiated' part of Dean's matrix and would allow communities to set the conditions of the participation including the norms and assumptions underlying the planning process. This may be ambitious given the statutory basis for planning in the global north, but it is hoped this project will offer some opportunities to move towards this goal or at least highlight the practical and professional barriers to a planning system based on co-production.

\section{Participatory democracy and legitimacy}

Legitimacy is critical in deriving moral authority for public institutions (Rawls, 1993). Traditionally it is based on consent through democratic processes, a system of elected representatives given authority to act on behalf of their constituents. The loss of trust in these traditional democratic processes has shifted the focus to participation as a source of legitimacy (Davoudi \& Cowie, 2015). As Fung argues "the principal reason for enhancing citizen participation in any area of contemporary governance is that the authorized set of decision makers -typically elected representatives or administrative officials-is somehow deficient. They may lack the knowledge, competence, public purpose, resources, or respect necessary to command compliance and cooperation." $(2006$, p67)

This section now outlines the theory of legitimacy within participatory planning. Using Hannah Pitkin's (1967) theory of representation it asks: how does a community group organise their representatives and what impact does this have on the legitimacy of any decision made by the group?

Traditionally planning decisions are made by elected representatives on the advice of professional planners. Non-elected representatives play a significant role in the planning system. As part of the consultation process, self-selecting community groups will seek to influence the decision by lobbying or submitting evidence. More recently the Localism agenda has devolved plan making powers to self-selecting neighbourhood forum.

Legitimacy can be founded on the process, the outcome or a mixture of both (Cowie \& Davoudi, 2015). This project, by replicating the planning process, only examines procedural legitimacy. The legitimacy of a process can be influenced by a number of factors. Fung (2006) highlights 3 issues: who participates?: How do they communicate and deliberate?; and what is the connection between 
their deliberations and the public policy outcome? Others highlight the importance of the choice of representatives who co-ordinate and manage the process on behalf of the community (Davoudi \& Cowie, 2013).

The work of Hannah Pitkin (1967) also focused on the nature of representation and its relationship to legitimacy. Pitkin (1967) argues that the relationship between citizens and representatives is that of an agent and principal. As part of the selection process the representative is given a mandate to act on behalf of those they represent. This mandate lasts until the next time they have to seek authority (i.e. stand for election) to act as a representative. For Pitkin (ibid) there are four forms of representation and the public choose their representatives using one of these forms: Formalistic; Symbolic; Descriptive and Substantive. The four forms of representation can be adapted to address the issue of community representation as follows:

- Formalistic representation is based on a formal process of selection. This may be a show of hands or may be demonstrated by a consensus view of the community involved.

- Symbolic representation is based on the fact the community feels the representative understands their concerns and will act on them.

- Descriptive representation is based on the representatives reflecting the demographic makeup of a community.

- Substantive representation concentrates on the outcome of the process. As long as the outcome is acceptable then the nature of the representation is secondary.

It is worth noting, later writers such as Saward (2006) have criticised Pitkin's forms of representation, which Saward considers to be overly structuralist and neglects the importance of the represented (2006). It can be argued that Pitkins view of representation is uni-directional and does not reflect the nature of modern political activity. Saward's post-structuralist analysis in contrast highlights the idea that the relationship between the representative and the represented is ongoing and is constantly being formed and reformed as the political process unfolds. Saward's analysis particularly concentrates on the process of representation in the new self-organising political groups such as 'Occupy Wall Street' and 'The 99\%' (Judge, 2014). In these situations it is not realistic to think of the representative -represented relationship as a principal - agent relationship as may have been the case in traditional political processes (ibid). Saward argues that in these new organizations the representatives make a 'representative claim' (2006) to an audience in relation to the group they are seeking to represent. Only if the audience accept the claim can it be said that the claimant is indeed the legitimate representative of those they are seeking to represent.

\section{Community participation and political modulation}

Rannila \& Loivaranta (2015) highlight that the disconnection between communities and professional planners can lead to antagonism and conflict within the planning system. As Bishop (2015) points out this is partly due to the nature of the participatory process and poor design on the part of those seeking to engage communities in planning. Participation is often perceived as tokenistic and part of a tick-box exercise that has no material effect on the planning outcome. 
Participation is not just about the selection of particular methods, it needs to encompass the totality of the process. This includes setting out a degree of understanding about the nature and scope of the participation, in effect managing expectations. It is understanding the power inherent in the statutory process and the inflexibility this can cause which limits both planners and communities agency in the process.

At the other end of the process it needs to be about creating a shared vision and understanding about the outcomes resulting from the participatory process. This often requires the community to absorb a certain amount of expert knowledge before they are competent to take a more formal role in the planning process (Cowie et. al. 2015). This process of empowering the community can be problematic as what the planners consider to be educating the community can feel like manipulation and co-option from the point of view of the community.

Further the steps those in authority take to impose the technocratic statutory process which planning requires on to community planning has been termed 'political modulation' (Parker \& Street, 2015). Political modulation occurs when any constraints are placed on the ability of the community to participate in the planning process. Parker and Street (ibid) highlight practice such as placing time constraints on certain activities or the requirement to submit of evidence, to the more covert such as the imbalance in resources between well-funded local authorities and developers and the limited resources of community groups. These forms of modulation can therefore counteract the benefits gained from taking a more collaborative approach to planning. Parker \& Street (ibid) go on to highlight that this is not a one sided battle, communities themselves are also able to adopt forms of political modulation as a way of regaining some degree of power and control over the process. This gap between the unfettered expectations of the participants and the constraints imposed by the system is one of the significant problems faced by participatory planning.

\section{Performativity and planning}

For Gallent et al. (2015) devolving more planning powers to communities not only improves decision making it also open a space for communities to engage in issues which have a societal impact. Issues such as an aging population, climate change and the globalisation of economies and markets. Getting communities to engage with these complex problems is difficult. This project investigated whether using a theatrical performance was a way of facilitating communities in such discussions.

Norman Denzin's (2003) performance ethnography is a theatrical method of exploring individual's lived experiences, particularly marginalised voices, through the performance of their stories. Denzin's work focuses on issues of race, gender and class. It seeks to give space to participants to tell their story in the form of a play. By getting the subject of the research to perform their interpretation of the world Denzin argues the problems of traditional forms of research, i.e. the mediating voice of the interviewer which is found in the transcribed interview, can be overcome. With performance ethnography the interview is a co-produced creative endeavour between the interviewer (the researcher) and interviewee (audience). Performance in this method is the transmission of an inner dialogue and subjective understanding on the part of the individual into an explicit narrative. This builds on Goffman's (1959) work which contents all life is a performance in 
which we play a role which is appropriate to the circumstances of our life. Denzin's performance ethnography draws out the roles we want to play but are prevented from doing so by societal norms and power relationships.

Another proponent of theatre as a means of facilitating transformative dialogue is Augusto Boal (1995). Boal's 'Theatre of the Oppressed' seeks to explore problems faced by society and in particular communities, in a detailed and forensic way. The method requires the audience to become 'spect-actors' and take part in the performance as a way of developing solutions to the problems being examined (Boal, 2004). Later, Boal's (1998) framework for 'legislative theatre' attempts to use theatre as a tool for better and more equitable decision making. Whilst not the template for the Town Meeting, the project shares a similar framework with citizens as spect-actors and empowered diologue between citizens and legislators the ideal outcome.

A further academic area where theatre has been used to tackle more open ended issues is in the field natural resource management. Conservation Theatre has been used for some time as a tool in community-based natural resource management (Heras \& Tabara, 2015). The benefit of theatre in these situations is that it is not just about transmitting facts about a particular ecosystem, it is about engendering a reframing of the problem and developing adaptive capacity within the community (ibid).

These methods all draw, to differing degrees, on the idea of performativity. This is the idea that people take on a persona and play a role in everyday life according to the norms and customs of the society in which they live (Goffman, 1969). The perfomativity of planning is evident in the description of the opening of the play set out in the first paragraph. Each person who takes part in the planning process has a role and that role is predetermined to a substantial degree by both the statutory process of planning and the norms and customs of the community and society in which the planning process is being conducted. This highlights why place matters so much in attempts at collaborative planning (Healey, 2010) as each place will have its own dominant culture and norms within which the statutory planning process must interact.

\section{Methodology}

This performance based project used a play as a tool for public participation in planning. A local theatre company had concept for a play centred on an official who was late for a meeting at which some important community decision was to be made. This was circulated to researchers who were invited to suggest a scenario relating to their research which fitted this situation. The author responded suggesting community engagement in planning may be a suitable subject for the play. The theatre group agreed and the project was under way.

The next stage was to develop a scenario for the play. This had to be plausible enough to work as a research case study but also have enough drama to capture an audience's attention and provide an entertaining evening. It was decided to use a fictitious place rather than a real place to emphasis the theatricality of the play. This allow the audience to have fun, as citizens of the fictitious town, with the scenario during the play leaving afterwards with a revised perspective on the planning system generally. The narrative for the play was then developed through an intensive collaboration between the researcher and the theatre company. 
The scenario chosen was taken from real life. A town founded to service an open cast mine has to move to allow the mine to expand. The alternative is that the mine closes spelling economic disaster for the town. This is the stark choice facing the audience. The play models aspects of a major planning decision, although for obvious reasons, 18 months of planning process had to be condensed into around 90 minutes. Such an abstraction of the planning process probably does limit the practical lessons that can be learnt from the play but does capture the essence of planning such that many participants commented afterwards how true to life they felt the play was. The play does retain the core essence of wicked planning issues, its complexity, the balance of interests and the constraints on decision making. The play starts with the community receiving the details of the planning proposal and being asked to formulate a response. The play then moves on to explore how the group, through the representatives, seeks to communicate its views to those who will take the ultimate decision.

The play is narrated by a junior planning officer. It is made clear from the outset that the officer is there to facilitate the process and clarify any questions of fact the community may have. The researcher also plays a minor part in the performance, playing the planning officer's superior who is undertaking an appraisal of his work. This provides a fiction that enables the researcher to be present and observe the performance from within.

The play has two acts. In Act I the scenario is developed and the audience work though some icebreaker activities to allow them to explore the fictional town and to get to know each other. At the end of the act they are asked to explore their reaction to the situation and formulate their response to the proposed development. At this stage they are also asked to choose two representatives from the community to communicate the response to the government minister responsible for the final decision the following day. Act one finishes with the actor receiving a phone call from the minister informing the community that in fact the Prime Minister has made the decision without hearing from them. Citing the national economic interest the Prime Minister has decided the town will be demolished, a new town built further away from the mine and the mine allowed to expand.

The second act is about how the community react to the news that the decision has been made without their views being considered. This part of the play has no formal structure and the direction taken is entirely down to the audience. The audience are offered an opportunity to form a 'Community Heritage Board' (CHB) akin to a neighbourhood forum through which they can gain a limited amount of planning power. The $\mathrm{CHB}$ is constituted of four members of the community who are chosen by the audience. The CHB has the power to plan aspects of the new town and during the play has the ability to choose one building from the old town which will be demolished brick-by-brick and re-constructed in the new town.

The play is thus structured in such a way that the audience to choose representatives at two stages of the process. In act one. the audience is able to choose two representatives without any constraint. As part of the process of choosing the representatives the audience is asked to be explicit in deciding the manner in which they select their representatives. In act 2 to the audience are invited to select members of the $\mathrm{CHB}$. At this stage they are asked to complete a short questionnaire indicating what they feel is the best way to choose representatives. The questionnaire gives the 4 forms of representation derived from Pitkin (1967); "Formalistic: Do they speak for the represented? Symbolic: Do they stand for the represented?; Descriptive: Do they resemble the 
represented?; Substantive: Do they act for represented?" (Davoudi, 2013:5 cited in Davoudi and Cowie, 2013: 563) The audience are asked to select which ever they feel is the most appropriate one.

A minimal stage set was designed for the play, recreating a typical community venue where a consultation meeting of this type may take place. The set consists of 4 free standing notice boards which contain a variety of notices and displays normally found in community venues. Props are also used as part of the ice-breaker exercises. To add to the atmosphere a radio program was recorded by the theatre company. Purporting to be a local radio station that was played to the audience as they arrived for the show. It was also decided to develop secret facts that would be given to the audience with the aim of giving them a fiction they could use to engage more personally in the play. These were handed to the audience as they arrived in a sealed envelope. There was a rough $50-50$ split between those audience members who utilised the secret information to participate in the play and those that did not. Often an audience member would use the secret information as a way of entering the discussion or dialogue.

The play was tested in the normal way with two preview (pilot) performances to an invited audience. These preview audiences were comprised of academics and theatre professionals. One aspect of the pay we changed as a result of the pilot performance was to change the way the minister's decision is related to the audience. In the pilot the planning officer discovers an email sent previously, but not read, outlining the minister's decision. This put the blame on the Planning Officer for the wasted effort. Later shows had the decision being made and communicated during the performance. The fiction being the minister was meeting the Prime Minister at the same time as the Town Meeting was taking place.

Once ready the show was booked to appear in a range of theatre and community venues. The initial tour took place in April \& May 2015. There were a 6 performances in a range of venues, traditional theatre venues and community centres ${ }^{1}$, across the north of England. There was a further tour in October 2015 where the play was performed in 2 more theatre venues. The play was advertised as any other play would be and the audience bought a ticket to attend, though Northumberland County Council sponsored the community performances in Northumberland which meant tickets were free. Prior to booking the ticket audience members were informed of the research element within the play and the fact they would be asked to participate fully in the performance.

The play was specifically designed to prompt the audience into thinking about how a community can organise itself to respond to a planning proposal which will have a transformative affect. The play also directs the audience to consider issues of representation and legitimacy in such a process. As will be seen from the discussion later the play also inadvertently provided a space for the audience to address the issue of knowledge and legitimacy in the planning process and particularly the role of planning professionals in community participation in planning.

\footnotetext{
${ }^{1}$ The first tour venues were: Northern Stage; Newcastle; Glendale Centre, Wooler; Theatre Deli, Sheffield; The Maritime Centre, Newbiggin-by-the-sea; Fourways Centre, Amble; and The Customs House; South Shields. The second tour venues were: Slung Low, Leeds \& NE Youth Focus, Gateshead.
} 


\section{The Performances}

Research material from each performance is collected in a number of ways. The researcher observes and takes notes during each performance. Following the performance the audience are invited to stay for a post-show discussion. The post-show discussion started with a reminder of the research aims and an invitation to the audience to reflect on their reaction to the play. The discussions were free ranging but the researcher did use a number of pre-prepared questions to elicit information about issues of representation, fairness and the process of planning. The postshow discussion was facilitated by the actor (also a trained facilitator) whilst the researcher took verbatim notes. Due to the nature of the venues it was felt impractical to record the post-show discussions.

In addition to the field notes and post-show discussion record, audience members were asked to indicate their age and educational attainment after the show. A note was made of the gender balance of the audience during the show.

The data from the field notes taken during the performance and during the post-show discussion, were then transcribed as soon as possible following the performance. Themes were identified in the data and coded for analysis. Initial themes, representation and legitimacy, relating to the research questions were selected with additional themes emerging through the analysis. The additional themes that emerged during the analysis related to demographics and the fairness of the process.

\section{Findings and discussion}

\section{The Audience}

Figures 1 and 2 show the age and educational profile of the audience. These fit the profile of the typical theatre goer (Chan \& Goldthorpe, 2015) and the typical citizen who volunteer in their communities in a range of circumstances (Brodie et al., 2009).

\section{Insert figures $1 \& 2$ here}

The initial pattern which stands out from the audience profile is the lack of middle-aged people. This is understandable as this is the group which has the least amount of spare time. They often have child care responsibility and work commitments. These are often the type of people who are also unlikely to participate in community activities (Brodie et al., 2009). The overall figure masks a significant difference between the various venues however. It should be noted that the Sheffield performance included an invited group of homeless adults who had been working with the theatre on a project supported by Shelter. Figure 3 shows the audience profile broken down by individual venue.

\section{Insert figure 3 here}

Here a clear difference can be seen between the community venues located in rural and peri-urban areas and the theatre venues located in large urban centres. The less urban community venues tended to have an older demographic. This contrasts with the urban venues which had a much more balanced audience. What is also interesting is that this differential in demographics across the venues is not mirrored in the educational attainment data. This shows a consistent pattern with 
those with an undergraduate degree or higher being the dominant audience member type for all venues. This again correlates with reviews of civic engagement which show the better educated are more likely to participate in civic life (Brodie et al., 2009).

The impact of the audience demographic was clear in the structure of the play. During the first act the audience are happy to act as a single group. All age groups within the audience participated in the process and engaged in well mannered debate. Often one or two audience members, of differing ages, would take on a degree of responsibility to coordinate the debate. This audience cooperation however often broke down in the second part of the play. Once the decision had been made and it was clear the meeting so far had been somewhat futile, the difference in reaction by each age group within the audience was marked. For the older members of the audience the news that the decision had been made seemed to confirm their expectation of participation. They wanted nothing more to do with the process. In a number of performances this refusal to participate in the process any further took a symbolic form in the tearing up of the Heritage Board information sheets and in another Benji was ejected from the set (a first for the actor; to be thrown out of his own play!).

In contrast to the older age group, the younger audience members took the news of the decision in their stride. They often argued to remain in dialogue with those in authority and looked to Benji as an ally in their attempts to regain some control over the process. The starkest example of this division of the generations was during the Newcastle performance of the play. The two age groups literally divided, standing on either side of the stage. One of the younger members of the audience commented on the feedback card for the show "Ruined a bit at the end by uncooperative participants". The field notes from the performance at the Customs House, South Shields also highlight this:

However early in the process a note of cynicism is introduced by an outspoken older member of the audience: "we are just being asked to be good boys and girls and do what they say!" This is countered by younger members of the audience who argue for an open discussion about the possible options open to the town.

This idea outlined in the quote from the older audience member highlights a constant theme in the older members of the audiences' view of participation in planning. The older members of the audience were perhaps more sensitive to the issue of manipulation and exploitation (real or imagined) than the younger members of the audience. From the outset they seemed to be of the opinion that the consultation would be a charade. In some ways they felt their role within the planning process was to challenge and question authority. It could be argued such an attitude can became self-fulfilling, a failure to engage willing often caused the process to break-down without any meaningful impact thus confirming their fears. This mirrors findings in the US which found the younger generation "seek ways to become more deeply engaged with the public problems they care deeply about and may even expect a deeper, more discursive level of engagement with organizations than their predecessors" (Fung, 2015: 518)

The demographic make-up of any community is therefore an important factor in participatory planning. It is clear older members of the community start the process with a healthy dose of scepticism which needs to be overcome. Further work is needed to understand how these demographic differences can be anticipated and overcome in order to produce a more constructive 
participatory process. It may be planners need to ensure a broad spectrum of ages are engaged in the neighbourhood planning process. Also greater transparency in the process may help overcome the scepticism of certain groups and be beneficial to all.

\section{The issue of representation}

One of the main research questions this project sought to investigate was how legitimacy and representation are negotiated in participatory planning. As outlined previously, within the structure of the play there are two points where the audience is asked to choose representatives. In the first act of the play the two representatives are asked to convey the decision made by the community about the town's future to the minister. The audience is asked to decide who their representatives will be, explain how the decided who the representatives should be and agree on the message the representatives should convey to the minister. There are no other stipulations as to the choice of representatives. The audience were given 15 minutes to complete this task.

What was striking was that in every case the audience spent the vast majority of time discussing the future of the town. Only when prompted towards the end of the allotted time, often with only a minute or two to go, did they turn to deciding the representatives. The choice was often to select those who had been most vocal during the debate or had exhibited some leadership or organisational skills. Prior to the performances we had expected the issue of representation to be of equal importance to the issue of process. In a number of instances, the issue of representativeness was raised only once the representatives had been chosen. Representational legitimacy was raised in relation to aspects: were the representatives descriptively representative and were the representatives symbolically representative using Pitkin's (1973) forms of representation. In most cases where the issue of descriptive representation arose it was around issues of gender balance. Over all the audience was $60 \%$ female but in 6 of the 8 performances it was decided to be fairer there should be both a male and female representative

In the case of symbolic representation ('do they speak for the represented?') the issue was more often than not about how the diversity of views could be represented. During the discussion the audience was often split 50-50 between moving the town and continuing mining or else closing the iron ore mine and finding a new alternative future. In many cases there were strenuous efforts to find a win-win solution, keep the mine and keep the town. When informed this would not be possible in every instance the audience selected one representative to reflect each side of the debate. This in effect abrogated their decision to the minister. The point, that the group had avoided making a decision, was raised in the post-show discussion. The justifications giver were a lack of information and that such a significant decision was too big for those present to make on behalf of the whole town.

Initially we thought the first justification, a lack of information, had resulted from a flaw in the play's production. In the test performances we did not supply any detailed information about the mine activity and the proposal to relocate the town. For the main performances we tried, via Benji, to answer these questions as far as possible when they arose during the performance. No matter how clear we were in relation to these issues the groups always cited a lack of detail and information as a reason for not making a definite decision. 
The second explanation for the lack of a decision related to the legitimacy of the group. In the play we present the town as having a population of 20,000. Many suggested having a group of 25 making a decision on behalf of 20,000 was not legitimate. The fact that the group had no democratic mandate was a significant issue when the group considered their legitimacy to make such a decision. The audiences also highlighted the fact that the decision affected future generations as much, if not more, than the current generation. The ability of such a small group to act on behalf of both current and future generations was therefore questioned.

One further explanation for avoiding making a clear decision, mentioned during the post-show debates, was the fact that in such a divided situation coming down on one side or the other risks alienating half the population that didn't agree with your decision. There is a social cost to making the decision. The idea that greater participation by communities in decision affecting will lead to greater satisfaction with the outcome, even if they disagreed with the decision, may also need to be reassessed, particularly for significant decisions (Gallent, 2013, Sturzaker \& Shaw, 2015)

Through the play we have been able to empirically test Pitkin's theory and observe how communities consider the issue of representation. Pitkin does not consider which of her 4 forms of representation to be the best but suggests all 4 play a role in determining the legitimacy of representation. Our project has shown firstly the issue of representation is not the primary issue in the legitimacy of planning. Legitimacy tends to be secondary to issues of fairness and due process.

\section{Political modulation and participation}

The most significant event within the performance is the point at which the audience is told the decision has been made by a higher authority. This aims to mirror the situation where a major planning decision is 'called-in' by a minister who then makes the decision themselves. In this case the decision is to demolish the existing town, build a new town $3 \mathrm{~km}$ away and expand the mining activity. The obvious difference with reality is the speed at which all this happens, a necessity to achieve a theatrical performance.

During the first half of the play, the audience has been split roughly 50/50 between those who wish to close the mine and find a new future of the community on the one hand and those who are happy to move the town. During the deliberations, the audience were very conscious of making sure all aspects of the debate were heard and in the majority of performances the group would periodically have a show of hands to see what the general division of opinion was amongst the group. This open debate and the respect shown for differing viewpoints could be characterised as being agonistic rather antagonistic (Rannila \& Loivaranta, 2015). This has the benefit of being constructive, many groups devised very inventive ideas for the future of the town, but has the problem of not achieving a consensus. It also poses a problem for planning as many of the options being debated by the group, many of which were very creative, would not be a material consideration in a planning sense. This is a significant problem for participatory methods. The risk is that expectations are raised to a level which is impossible to satisfy (Bishop, 2015). This insight has stimulated the development of a new version of the play which allows more constructive creativity and avoids reducing decisions to binary extremes.

Following the announcement that the decision has been taken away from the group, the situation and atmosphere in the second half of the play is markedly different. This first obvious shift is in the group's attitudes to the problem. Whereas during the opening discussions there is an equal split 
between the two options, once the decision is announced the majority of the group take the view that the town must stay. In addition to the switch in attitude to the two options there is also a marked shift in attitude to the process itself. It is at this point the group start to discuss direct action, sabotage of the equipment, chaining themselves to the fences, even attacking the mine. The anger is also often directed at Benji, the planning officer. Benji had paper thrown at him, he was sworn at and on one occasion manhandled to the centre of the stage by a particularly irate audience member. It could be argued the scenario played out in the performance is an extreme one and one designed to achieve a degree of dramatic effect. However during the post show discussions a surprising number of people reflected that their anger during the play was mirrored by their previous experiences of planning and the anger they felt with the real life planning system. This feeling of powerlessness seems to overwhelm the previous rationality, openness and consensual action which were the dominant feature of the first half of the play. This shows the reaction communities have to what they perceive as an unjust process. The immediate aim is to wrestle a degree of control over something back from those in power. The only way this power can be achieved is through a refusal to have anything else to do with the process. This finding mirrors the findings of Parker and Street (2015) and highlights the risks involved in seeking to impose any form of political modulation on the community planning process.

\section{Conclusions}

This project aimed to create a piece of drama to explore people's experiences of participatory planning. The experience thus far suggests theatre can be a powerful tool to engage communities in this area.

The research findings have highlighted the importance of fairness and transparency in the planning process. The problem with current consultation exercises is that there is little space for each side to understanding the other and to frame planning problems within wider socio-economic change. The creativity that could be a vital ingredient to innovative planning is lost. This risks each party retreating into an adversarial and entrenched position. The research has shown how often this is much more important than issues of representation. The groups taking part in the research did debates issues of descriptive and symbolic representation as part of the process of choosing their representatives' but this was always a secondary consideration to issues of fairness and transparency.

The research has also found evidence, that mirrors other studies (Fung, 2015), of a difference in attitude between the generations. Each age group approaches participation in planning with a clear set of preconceptions. To be effective these must be appreciated and allowed for in the process of participatory planning. The research reported here did not seek to engage specific age groups save in one instance. Further research is therefore needed to understand the impact socio-demographic factors such as age or ethnicity have on participation in planning.

The research has also shown that, when given free reign, there is a natural tendency within community groups to find a compromise solution through creativity. When such a compromise is impossible the group then seeks to avoid making the tough decision. This avoidance of conflict and making tough decisions is often decried by external actors as being unprofessional and unreasonable. This difficulty can be overcome though careful planning of the whole process as suggested by Bishop (2015) but can also be overcome through the use of techniques such as theatre 
to work through these impossible 'wicked problems' in a safe and inconsequential environment. When the community is faced with the real thing they are better able to manage expectations and agree the limits to the process. The next stage of the project is now underway. The new version of the play has taken the insights gained in this initial experiment, such as the need to allow creativity whilst at the same time retain an understanding of the statutory limitations of the planning system, and create a framework for communities of all background to work together. The new play also aims to develop trust between planners and communities through a mutual understanding of the required and intended outcomes of both communities and planners.

The play has also shown there is a latent willingness to engage in planning issues, if we can get 30 people to come out and debate spatial planning on a wet Monday night in February there is hope. Practitioners such as Jeff Bishop (2015) and David Farnsworth (2011) have both set out clear manifestos as to how meaningful participatory planning can be practically achieved. What this project emphasises is that these approaches need to capture the creativity and imaginations of the community and channel it into a process which satisfies the statutory planning system. This may be through the explicit recognition that everything that gets debated and all ideas generated by the process may not get incorporated into the final plan. There is anecdotal evidence that this is already happening with the neighbourhood plans that have been adopted. Most are longer than many local plans and contain many 'superfluous' elements which are significant for the community but immaterial in terms of the planning policy. Further work is needed in this area to see how neighbourhood planning could bridge some of these difficulties in creating a shared vision and ensuring the legitimacy of communities that engage in planning.

\section{References:}

ARNSTEIN, S., (1969). A ladder of citizen participation. Journal of the American Institute of planners, 35, pp.216-224.

BAILEY, N. \& PILL, M. (2015) Can the state empower communities through localism? An evaluation of recent approaches to neighbourhood governance in England. Environment \& Planning C:

Government and Policy Vol. 33 pp289-304

BISHOP, J. (2015) The Craft of Collaborative Planning: People Working Together to Shape Creative and Sustainable Places. London: Routledge.

BOAL, A. (1995) The rainbow of desire: The Boal method of theatre and therapy. London: Routledge

BOAL, A. (2004) Theatre of the oppressed. [available at

http:theatreoftheoppressed.org/en/index.php?useFlash=0] (date accessed 9.2.2016)

BOAL, A. (1998) Legislative Theatre. London: Routledge

BRADLEY, Q. (2015) The political identities of neighbourhood planning in England. Space and Polity Vol. 19 pp97-109

BRODIE, E., COWLING, E. \& NISSEN, N. (2009) Understanding participation: A literature review. London: Institute for Volunteering Research [available from http://pathwaysthroughparticipation.org.uk/] (dates accessed 4.2.16) 
BROWNILL, S. (2009) The Dynamics of Participation: Modes of Governance and Increasing Participation in Planning. Urban Policy \& Research Vol. 27 pp357-375 DOI

$10.1080 / 08111140903308842$

CHAN, T. \& GOLDTHORPE, J. (2015) The social stratification of theatre, dance and cinema attendance. Cultural Trends Vol. 14 pp193-212

COWIE, P \& DAVOUDI, S. (2015) "Is small really beautiful? The legitimacy of neighbourhood planning." in eds. Davoudi, S. \& Madanipour, A. (eds.) Reconsidering Localism. Routledge: London COWIE, P., VIGAR, G., DAVOUDI, S. \& MADANIPOUR, A. (2015) Hyper-local planning in England: territorial governance at the neighbourhood scale. In eds. Schmitt, P. \& Van Well, L. Territorial Governance Across Europe: Pathways, Practices and Prospects. London: Routledge

DAMER, S. \& HAGUE, C. (1971) Public Participation in Planning: A Review. Town Planning Review. Vol. 42(3) pp217-232

DAVOUDI, S. \& COWIE, P. (2013) Are English neighbourhood forums democratically legitimate? Planning Theory \& Practice Vol. 14 pp562 -566 DOI 10.1080/14649357.2013.851880

DEAN, R. (2016) Beyond radicalism and resignation: the competing logics for public participation in policy decisions. Policy \& Politics Online only DOI 10.1332/030557316X14531466517034

DENZIN, N. (2003) Performance Ethnography: Critical Pedagogy and the Politics of Culture. Thousand Oaks, CA: Sage

DOLAN, J (2005) Utopia in Performance: Finding Hope at the Theatre. Ann Arbor: University of Michigan Press

FARNSWORTH, D. (2011) A network route to Localism in Planning. Town \& Country Planning March 2011

FUNG, A. (2006) Varieties of Participation in Complex Governance. Public Administration Review. Vol. 66 pp 66-75

FUNG, A. (2015) Putting the Public Back into Governance: The Challenges of Citizen Participation and its Future. Public Administration Review. Vol. 75(4) pp513-522

GALLENT, N. and ROBINSON, S. (2012), Neighbourhood Planning - Communities, Networks and Governance. Bristol: The Policy Press.

GALLENT, N. (2013) Re-connecting 'people and planning': parish plans and the English localism agenda. Town Planning Review vol. 84 pp371-396. Doi: 10.3838/tpr.2013.20

GALLENT, N., HAMIDUDDIN, I. \& MADEDDU, M. (2013) Localism, down-scaling and the strategic dilemmas confronting planning in England. Town Planning Review, Vol. 84(5) pp563-582 doi:10.3828/tpr.2013.30

GOFFMAN, E. (1969) The presentation of self in everyday life. Penguin Press: London HEALEY, P. (2006) Collaborative Planning: Shaping places in fragmented societies. London: Macmillan HEALEY, P. (2010) Making better places: The planning project in the twenty first century. London: Palgrave Macmillan 
HEALEY, P. (2016) Innovation and Transformative Change in Place Governance. Paper presented to the Innovations in Spatial Planning Seminar. February 2016. IRS: Erkner, Germany

HERAS, M. \& TABARA, D. (2015) Conservation Theatre: Mirroring Experiences and Performing Stories in Community Management of Natural Resources. Society and Natural Resources, online publication. http://dx.doi.org/10.1080/08941920.2015.1095375

HILLIER, J. \& HEALEY, P. (2008) Contemporary movements in planning theory: Critical essays in planning theory vol. 3. Ashgate: Aldershot

JUDGE, D. (2013) 'Word from the street': When non-electoral representative claims meet electoral representation in the United Kingdom, British Politics Vol. 8 pp 388-409

LOWNDES, V., PRATCHETT, L. \& STOKER, G. (2001) Trends in public participation: part 2 - citizens' perspectives, Public Administration. Vol. 79 (2) pp445-455

PARKER, G. \& STREET, E. (2015) Planning at the neighbourhood scale: localism, dialogic politics, and the modulation of community action. Environment \& Planning C: Government and Policy. Vol 33 doi:10.1068/c1363

PARKER, G., LYNN, T. \& WARGENT, M. (2015) Sticking to the Script? The co-production of neighbourhood planning in England. Town Planning Review. Vol. 86 pp519-536 doi:10.3828/tpr2015.31

PITKIN, H., (1967). The concept of representation. Berkeley: Univ of California Press.

RANNILA, P. \& LOIVARANTA, T. (2015) Planning as Dramaturgy: Agonistic Approaches to Spatial Enactment. International Journal of Urban and Regional Research. Vol. 39 pp788-806 doi:10.1111/1468-2427.12214

RAWLS, J. (1993) Political Liberalism. New York: Colombia University Press

SAWARD, M. (2000) Less than meets the eye: democratic legitimacy and deliberative theory. In ed. Saward, M. Democratic Innovation: Deliberation, representation and association. Abingdon: Routledge

SAWARD, M. (2006) The Representative Claim. Contemporary Political Theory, Vol, 5 pp297 - 318 SKEFFINGTON COMMITTEE, (1970). People and Planning: Report of the Committee on Public Participation in Planning (the Skeffington Committee Report). London: Routledge.

STURZAKER, J. \& SHAW, D.(2015) Localism in practice: lessens from a pioneer neighbourhood plan in England. Town Planning Review. Vol. 86 pp587-609 doi:10.3828/tpr.2015.34

WATSON, V. (2014) Co-production and collaboration in planning: The difference. Planning Theory \& Practice 15 pp62-76 doi: 10.1080/14649357.2013.866266 